ESKİ YAZI DİLLERİ: TÜRK YAZILI ABİDELERININN DİLLERİ*

Ethem Rahimoviç TENIŞEV

Rusçadan çeviren: Janılmırza BAPAEVA**

Özet

Türkçe dünyanın bilinen en eski dillerinden biridir. Türkçenin en eski yazılı abidelerinin dil ve üslup özellikleri bu dilin bilinen tarihini birkaç yüzyıl daha öteye götürebilecek niteliktedir.

Türkçe farklı sebeplerle dünyanın farklı bölgelerinde yayılma gösteren; her bir dalı / kolu ayrı bir edebî dil hâline gelen ender dillerden de biri olma özelliğine sahiptir.

Bu makalede, Türkçenin tarihî devreleri, eski Türk yazılı abideleri, eski Türk yazılı abidelerinin dilleri, Türk dilinin gelişme ve yayılma alanları ana hatlarıyla dikkatlere sunulmaktadır.

Anahtar sözcükler: Eski Türk yazılı abideleri, Türkçe, Türkçenin tarihî devreleri, Türkçenin yayılma ve gelişme alanları.

\title{
ANCIENT WRITTEN LANGUAGES: LANGUAGES OF THE TURKIC WRITTEN MONUMENTS
}

\begin{abstract}
Turkish is one of the most ancient languages in the world. Language and stylistic features of the most ancient written monuments in Turkish has a nature to take this language several centuries beyond its known history.

Turkish has a feature to be one of the rare languages which develops in many different parts of the world for many reasons; of which each field / branch becomes a literary language.

This article outlines the historical stages of Turkish language, ancient Turkic written monuments, languages of the ancient Turkic written monuments, development and spread of Turkish language.
\end{abstract}

Keywords: Ancient Turkic written monuments, Turkish, historical stages of Turkish, spread and development of Turkish.

Türk yazılı abidelerinin dilleri 3 kronolojik dönemde ele alınıp incelenmektedir: Eski Türkçe devri (5-10. yy.), Orta Türkçe devri (10-15. yy.), Yeni Türkçe devri (15-20. yy).

$\mathrm{Bu}$ tasnif genel tarih ilminde kabul görmüş tarihlendirme geleneğinden ayrılmaktadır ve yalnızca Türk dil bilimi için geçerlidir.

'Türk yazılı abidelerinin dilleri' terimi (eski Türk dilleri terimi gibi) bugün yaşayan, çağdaş lehçelerinin dışında kalan tüm Türk dili gruplarını kapsamaktadır. Türk yazılı abidelerinin dillerinin büyük kısmı (işlenmişlik, ağız üstü gelişmişlik, geleneklerin aktarılması,

\footnotetext{
* Janılmırza BAPAEVA tarafından Rusçadan Türkçeye çevrilen makale, Dr. Semra ALYILMAZ tarafından gözden geçirilip yayıma hazırlanmıştır.

** Doktora Öğrencisi; İstanbul Üniversitesi Sosyal Bilimler Enstitüsü, jenyacik@ hotmail.com.
} 
işlevsel-stilistik çeşitlilik bakımından) edebî dil statüsüne sahiptir. Küçük bir kısmı ise diyalektik ve yarı diyalektik şekilleri (konuşma dili, şehir konuşması) ihtiva eder.

Eski Türk dilleri, Türk boy ve halklarının genel göç istikametine göre (doğudan batıya doğru) şekillenmiştir.

İlk edebî yazı dili olan runik abidelerinin dili Oğuz, Uygur dillerinin karışımı temeline Kıpçak dil unsurlarının eklenmesiyle oluşmuştur. Bunlarda halk dili ve halk hukuk anlayışı ögeleri de mevcuttur. Stilistik işlenmişliği zayıf olmakla beraber Köl Tigin, Bilge Kağan, Bilge Tonyukuk, El Etmiş Kağan, Köli Çor, Moyun Çor gibi büyük Orhun yazıtlarındaki metinlerin gelişmiş stili, daha küçük Yenisey mezar taşları kitabelerinin stili, Altay yazıtlarının günlük stili dikkate değerdir. Runik yazıtların yayıldığı alan çok geniştir: Moğolistan, Güney Sibirya, Doğu Türkistan, Orta Asya, Kazakistan, Kuzey Kafkasya, Doğu Avrupa. Bunlar, çeşitli türlerdeki tarihî biyografik, kaya, taş, eşya üzerine yazılan özdeyiş yazılar, büyü, sihir, din ve hukuka dair metinlerdir.

Eski Uygur edebî dili Turfan, Kansu civarında Oğuz-Uygur esaslı runik yazıya Uygurcanın fonetik, gramer, leksik unsurlarının karışmasıyla oluşur. Başlangıçta kullanılmış runik alfabenin dışında Uygurlar, Uygurca olarak adlandırılan Soğd yazısının uyarlanmış şeklini, Mani ve Brahmi yazılarını da kullanmışlardır. Eski Uygurların edebî dili dinî edebiyat stilini (felsefi-didaktik), tıbbi, astronomik karakterde ilmî eserleri, resmi evrak (hukuki, ekonomik mahiyette) ve hususi yazışmaları içeren geniş tür-stil sistemine sahipti. Toplum içinde yaygın olarak kullanılmasına rağmen eski Uygur edebî dili daha ziyade yazılı iletişim arac1 idi.

Karahanl1-Uygur (Hakaniye, Buğrahan) edebî dili merkezî Kaşgar şehrinde bulunan ve batı sinırları Semerkant ve Buhara'ya dayanan Karahanlı devletinin topraklarında oluşmuştur. Bu döneme ait Arap harfleriyle yazılan eserler: İslam'a göre yaşayış, mutlu olma bilgilerini mesnevi nazım türünde işleyen Yusuf Balasagun'un 'Kutadgu Bilig' adlı eseri, Ahmet Yükneki'nin 'Atebetü'l- Hakayık'1, Mahmut Kaşgari'nin 'Divanü Lugati't-Türk'ü ve Kur'an tefsirleridir. Nazım türünün nesre göre daha gelişmiş olduğu görülmektedir. Türk lehçeleri üzerine Kaşgarlı Mahmut'un bu ilmî çalışması edebî dilde yazılan manzum parçaların yanı sıra ağız özelliklerini ihtiva eden örnekleri sunmasıyla ilgi çekicidir. Eski Uygur edebî dilinin temeli üzerinde kurulan Karahanl1-Uygur edebî diline oluşum süreci içinde her düzeyde yerli-millî unsurlar katılmıştır. Uygurcanın etkisi, sonraki yıllarda Arap alfabesinin yanında Uygur alfabesinin kullanılmaya devam etmesinde görülür.

Harezm-Türk edebî dilinin yayılış alanı, Siriderya'nın aşağı bölgeleri ve Altın Ordu

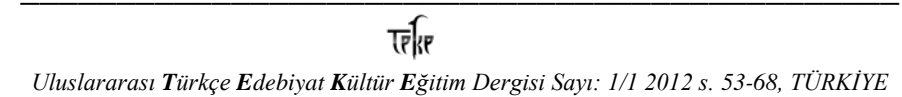

International Journal of Turkish Literature Culture Education Volume 1/1 2012 p. 53-68, TURKEY 
topraklarıdır. $\mathrm{Bu}$ dönemin eserleri şunlardır: Rabguzî’nin “Kısasü’l Enbiya”sı, İslâm'ın “Müinü'l- Mürid”i, Kutb'un 'Hüsrev ü Şirin'i, Harezmî'nin 'Muhabbetname'si, Kerderli Mahmud ibn Ali'nin 'Nehcü'l-Feradis'i. Başka bir ifadeyle, nazım ve nesir türlerinde çeşitli stillerde (dinî, felsefi-didaktik, içtimai karakterde) eserler meydana getirilmiştir. Bu metinlerin dilinin geleneksel, Oğuz-Uygur kısmı Karahanlı dönemi edebî dilinin tüm şekillerini temsil eder. Daha ziyade Kıpçak asıllı yenilikler bu kısma alınmıştır. Harezm-Kıpçak edebî dilinde Uygurcanın etkisi azdır; fakat bazı eserler yine de Uygur harfleriyle yazılmışıır.

Çağatay edebî dili, Orta Çağ Türk edebiyatı ve edebî dilleri tarihinde en parlak ve aynı zamanda sonuncu dönemi teşkil eder. Çağatay dili birçok kaynaktan beslenir (Ayrıntılı bilgi için V. V. Bartold, F. Köprülü, J. Eckmann'ın çalışmalarına bakılabilir). Çağatay dönemi yazılı eserlerinde geleneksel Oğuz-Uygur edebî dilinin temel unsurları azdır. Dil, Semerkant ve Andican gibi büyük şehir merkezlerinin ağız unsurları esas olmak üzere yeniliklerden müteşekkildir. Uygurcanın etkisi bazı eski Çağatay eserlerinin hem Arapça hem Uygurca yazılan nüshalarının bulunmasında görülmektedir. Çağatay dilinin en büyük özelliği yüksek edebî anlatım gücü ve terim zenginliğidir. Bu dönemin nazım ve nesir türlerini dinî, felsefididaktik, ilmî, hukuki, iş, mektup şeklinde yazılan eserler teşkil eder. Çağatay dilinin gelişmesi 3 safhada gerçekleşir:

1) İlk Çağatay devri - Nevayî (1440-1501) öncesi dönemdeki edebî eserler.

2) Orta veya klasik dönem - Çağatay dilinin altın devri. A. Nevayî’nin sanatı.

3) Son devir - klasik dönemin devamı. Bu dönemi Türk edebî dili takip eder.

Türk edebî dili, çağdaş Türk lehçeleri ile doğrudan bağlantılıdır. Tarih sahnesine çıkan çağdaş Türk dilli halkların her birinin ayrı bir millet olarak oluşmasında Çağatay dili edebî şekil olarak kullanılmıştır. Zamanla bu dilin yerli halk (şehir ve köy ağızları) unsurları ile etkileşimi neticesinde tek yazı dilinden birkaç yerli yazı varyantı oluşmuştur. Bunları "Türk edebî dili" olarak adlandırıyoruz.

Türk dilinin gruplarını şöyle dikkatlere sunmak mümkündür:

- Orta Asya (Özbekçe, Uygurca),

- İdil Nehri Bölgesi ( Tatarca, Başkurtça),

- Aral- Hazar (Kırgızca, Kazakça, Karakalpakça),

- Kuzey Kafkasya (Karaçay-Balkarca, Nogayca, Kumukça),

- Küçük Asya (Türkiye Türkçesi).

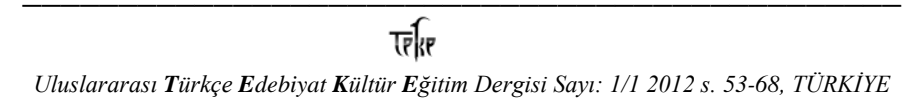

Uluslararası Türkçe Edebiyat Kültür Egitim Dergisi Sayl: 1/I 2012 s. 53-68, TÜRKIYE
ternational Journal of Turkish Literature Culture Education Volume 1/1 2012 p. 53-68, TURKEY 
Türkçenin ilk dönemleri çağdaş Türk millî edebî dillerinin şekillenmesinin başlangıç etabıdır. Aynı zamanda Türk boy ve toplulukları arasında Çağatay ve hatta ilk Harezm gelenekleri kesilmemiştir; halk bilimciler, Harezm ve Çağatay dairesine ait eski edebî eserlerden örneklerin çağdaş Tatar, Kazak, Karaçay ve Balkarlar tarafindan hâlâ söylendiğini belirtmektedirler.

Selçuklu (eski Anadolu Türkçesi, eski Osmanlı Türkçesi) edebî yazı dili Küçük Asya ve Kafkaslarda kullanılmıştır. Bu döneme ait Arap harfleriyle yazılan edebî mahsuller şunlardır: Ahmed Fakih'in 'Çarhname' adlı mesnevisi, Mevlana Celaleddin Rumî'nin, Sultan Veled'in, Sivaslı Burhaneddin'in, Şeyyad Hamza'nın manzum eserleri, Oğuzların epik anlatılarının anonim kitabı: 'Kitab-ı Dede Korkut'. Selçuklu edebî dili yapı olarak çağdaş Oğuz lehçeleri ile Uygurca unsurların karışmasından ibarettir. Uygur yazı geleneklerinin etkisi ünlülerin ayrı harflerle belirtilmesinde, 'ng' için iki harf kullanılmasında, kelimelerde eklerin kökten ayrı yazılmasında görülmektedir. Selçuk yazı dili, Oğuz grubu edebî dillerinin (Türkiye Türkçesi, Azeri Türkçesi, Türkmen Türkçesi) öncüsüdür.

Memluk-Kıpçak edebî dilini Mısır ve Suriye'de Arap-Kıpçak sözlükleri, Arap gramer okulu geleneklerinde yazılan Kıpçak dilinin gramer kitapları, dinî ve sosyal konularda yazılmış birkaç eser temsil etmektedir. İlmî, didaktik stilde ve saray edebiyatı stilinde eserler de mevcuttur.

Bulgar edebî dili, Kazan civarında ve İdil nehri boyunca çeşitli yerlerde bulunan mezar taşları kitabelerinin standart dilidir.

Türk yazılı abidelerinin dilleri arasında edebî dil statüsüne sahip olmayanlar da vardır. Kitabe dilinin işlenmişliği, stilistik çeşitliliği ve kendisinde diğer ağızların özelliklerini ihtiva ettiğine (ağız üstü gelişkenlik) dair yeterince delil yoksa, onu ağız olarak sinıflandırmak gerekir. Zemahşerî'nin sözcük bilimsel (leksikolojik) nitelikte olan 'Mukaddimetü'l Edeb' adlı çalışmasını ve birkaç Kur'an tercümesini bu tip ağız düzeyindeki Türk lehçelerine dâhil etmek lazımdır.

Eski Kıpçak ağızlarına dair kıymetli eserler: 'Codex Cumanicus' ve 'KamenetsPodolsk’ta keşfedilmiş Ermeni yazısıyla kaydedilen mahkeme hükümleri.

Böylece, eski ve orta Türkçe abideleri, edebî ve halkın konuşma dili (ağız) olmak üzere iki tip dili temsil ederler. Edebî diller iki çeşittir:

1) Yayılma alanı geniş (Merkezî ve Orta Asya, İdil Nehri Boyu, Kafkasya, Dağıstan) ve uzun süreli (7-20. yy.), esasını Oğuz-Uygur yazı dili gelenekleri oluşturan lehçeler. Bu gelenekler çok sağlamdır. Onun etkisi ilk başta doğudan batıya doğru, sonunda Çağatay dili 
aracılığıyla doğuya doğru geçer. Tek geleneğin etkisi Türk edebî lehçelerinin işlemesinin uzak alanlarında bile görülmektedir. Bu geleneğin millî öz ile birleşmesi bir lehçe çerçevesinde değişiktir. Olayın hareketleri (dinamiği) geleneğin zamanla bir lehçeden diğer bir lehçeye geçerken kama şeklinde darlaşması, halk dili unsurlarının ise, sürekli genişlemesi ve nihayetinde hâkim hâle gelmesinden ibarettir.

2. Birinci gruptakilere kıyasla daha küçük coğrafi ve zaman ölçeklerinde, birbiriyle dil gelenekleri bağlantıları olmayan Kafkaslar, Küçük Asya, Mısır, İdil Nehri Bölgesi’nde 1318 yy.lar arasında hâkim edebî lehçeler.

3. Konuşanların sayısı hakkında bilgi yoktur.

4. Eski Türk lehçelerinin genetik ilke temelinde kurulanlar; bunların birçok sınıflandırması vardır. Aşağıda bunlar üzerinde durulacaktır.

V. V. Radloff (1911)'un görüşüne göre eski Türk edebî dilinin temelinde fonetik ve morfolojik özelliklerin toplamına sahip 3 ağız yatmaktadır: Eski kuzey ağzı (Türk-Sirlerin dili), eski güney ağzı (Uygurca), karma ağız.

Eski kuzey ağzı Orhun (Köl Tigin, Bilge Kağan, Bilge Tonyukuk, Ongi, Hoyt Tamir), Yenisey (Hemçik, Yenisey, Abakan abidelerinde, Karabalasagun, Türkistan ve Turfan'da bulunan) yazmalarında kayıtlıdır. Radloff'a göre eski güney ağzı güneyde oluşmuştur ve Baykal gölünden güney taraftaki bölgelerde keşfedilen yazmalardan bilinmektedir:

Karma ağız, içinde kuzey ve güney ağızların özelliklerini birleştirmiştir. Mani ve Uygur yazısıyla yazılan Maniheizm esaslarını ihtiva eden eserler, Kutadgu Bilig'in Arap harfli Kahire nüshası, Budizm'in esaslarını içeren Uygur harfli eserler ('Altun Yaruk', 'Tişastvustik' $v b$.) bu ağzı temsil etmektedirler. Radloff, karma ağzı iki alt ağza ayırır: Batı (Huastuanift yazması, Kutadgu Bilig'in Kahire nüshası) ve doğu (Budizm'in esaslarını içeren Uygur harfli eserler).

A. N. Samoyloviç (1922), 6 fonetik ve morfolojik özelliği esas alarak Türk dillerini 6 lehçe grubu içinde değerlendirmektedir. Eski Bulgarca p-grubuna, Orhun-Yenisey ve Uygur abideleri d-grubuna, Çağatayca taglık grubuna dâhildirler.

S. Ye. Malov (1951), fonetik özelliklere göre Türk lehçelerini 4 gruba ayırır: en eski, eski, yeni, çağdaş. Eski Türk lehçeleri ilk 3 gruba girer: Bulgarca, en eski; runik ve eski Uygur yazıtlarının dilleri, eski; eski Kıpçak (Peçenek ve Polovets) ve Çağatay metinlerinin dili ise yeni.

N. A. Baskakov’un (1969), sınıflandırması kompleks özellikler üzerine kurulmuştur.

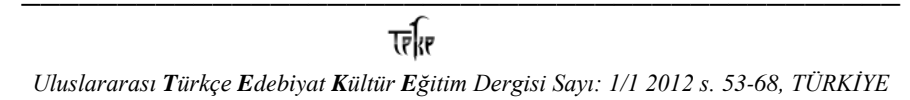


Eski Bulgar ve Hazar lehçeleri Bulgar grubunu, Peçenek, Selçuk, eski Osmanlı ve eski Azeri dilleri Oğuz grubunu, eski Kıpçakça (Kuman, Polovets)- Kıpçak grubunu, Karahanlı-Uygur, Harezm, Altın Ordu, Çağatay Türkçesi, eski Özbekçe Karluk grubunu ve bunların hepsi Türk dilinin Batı Hun dallarını oluş̧ururlar.

A. M. von Gabain'in runik ve Uygur yazıtlarının dilleriyle ilgili sınıflandırması öncekilerden farklı ilkelere dayanır. Ayırıcı özelliklerden biri, kelimenin ortasında y-n-ŷ fonemlerinin bulunması ve bu özelliğin diğer fonolojik ve morfolojik özelliklerle uyum içinde olmasıdır. y-ağzını Buda, son dönem Mani, Brahmi eserleri temsil eder; n-ağzı Mani ve bazı runik metinlerde, $\hat{y}$-ağzı runik ve Mani metinlerinin büyük kısmında kullanılmıştır. A. M. von Gabain'in bu sınıflandırması daha sonra D. Sinor ve O. Pritsak'ın ilaveleriyle tamamlanmıştır. A. M. von Gabain ve O. Pritsak'ın sistemi 1980 yılında A. N. Kononov'un sinıflandırmada yeni bir özelliğin (kelime köklerinde ve eklerinde dar ünlüleri geniş, ön damak ünlüleri arka damak ünlülerin takip etmesi) sunmasıyla gelişmeye başlıyor. Buna göre Türk lehçeleri iki gruba ayrılırlar: a (ä, o, ö) lehçeleri ve u (i, u, ü) lehçeleri. Eski lehçelerden a-grubunu Oğuz, Kıpçak, Çigil, u-grubunu eski Uygurca teşkil ederler.

Philologiae Turcicae Fundamenta'da makale olarak yayımlanan (1959) İ. Benzig, K. G. Menges'in sınıflandırması fonetik ve morfolojik özelliklerin uyumları üzerine kurulmuştur. İ. Benzig'in görüşüne göre Bulgar yazıtlarının dili Bulgar grubuna; Orta Çağ Oğuz (Kaşgarlı Mahmut), Selçuklu ve eski Osmanlı eserlerinin dili güney (Oğuz) grubuna; Kuman, Memluk Kıpçakçası batı Türk (eski Uygur-Kuman) grubuna; Çağatay, Karahanlı, Harezm Türkçesi doğu (Uygur) grubuna girer. K. G. Menges'in fikrine göre Orhun-Yenisey yazıtlarının dili eski (klasik) Uygurca, Karahanlı-Uygur, Harezm, Çağatay Türkçesi Merkezî Asya grubunu; eski Anadolu (Selçuk) ve eski Osmanlı Türkçesi güney-batı (Kıpçak) grubunu; İdil-Bulgar Türkçesi İdil-Bulgar (Hun-Bulgar) grubunu oluşturur.

Philologiae Turcicae Fundamenta'da kabullenilen şemada runik yazıtların ve eski Uygur yazmalarının dilleri eski Türk bölümünü oluşturur. Kumanca, Memluk, Ermeni Kıpçakçası orta Türkçenin batı grubuna, Karahanlı-Uygur, Harezm, Çağatay Türkçesi doğu grubuna dâhildir. Eski Osmanlıca güney Türk; Hun, Tuna-Bulgar, İdil-Bulgar dilleri ise, yeni Türkçenin Bulgar grubunu teşkil eder.

Eski Türk dilleri alanında yön tayin etmek için ilk önce $d-\delta$-y-r ortak özelliğini dikkate almak gerekir:

d-grubu: Runik ve eski Uygur edebî dilleri;

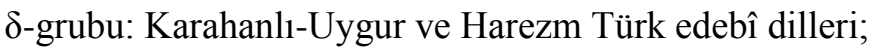

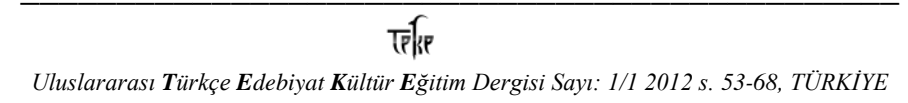


y-grubu: Çağatayca, Türk dili, Selçukluca, Memluk-Kıpçakçası, Kumanca (Codex Cumanicus), Ermeni Kıpçakçası;

r-grubu: Bulgar yazıtlarının dili.

Edebî dilleri tasnif ederken onların işlevsel yönü dikkate alınmalıdır. A. N. Samoyloviç (1928), tek bir Orta Asya Türk edebî dili olduğunu ve onun 3 gelişme devresinden (Karahanlı, Harezm, Çağatay) geçtiği görüşünü tasnifinde belirtir. Bu sınıflandırmanın temelinde büyük kültür merkezlerinde farklı dönemlerde değişen tek kitap geleneğinin istikrarlılığının ikrar edilmesi yatmaktadır.

5. Runik yazıtlardaki dilin işlenmişliği ve anlatım zenginliğine göre böyle bir dilin yazılı olarak kaydedilinceye kadar birkaç yüzyıl boyunca varlığını sürdürmesi gerekir. Muhtemelen, runik yazıtların dilinin temeli M. S. 1-2. yy.da oluşmuş, 7-9. yüzyıllarda ise gelişmesinin zirvesine ulaşmıştır. Eski Uygur edebî dili, V. V. Radloff'un görüşüne göre 8-9. yy.da runik yazıtların dili esasında kurulmuştur ve 13. yy başlarına kadar varlığını sürdürmüştür. 11-12. yy. eski Uygur dilinin etkisiyle Karahanlı-Uygur edebî dili meydana çıkmıştır. Onu takiben ve onun temelinde 13-14. yy Harezm-Türk edebî dili gelişir. 15. yy.da ise, bunlardan hareketle Çağatay dili şekillenmiştir (15-18. yy.).

16-18. yy.da (son devir) Çağatayca'nın yerine Türkî dili geçiyor. Tarih sahnesine Oğuz, Kıpçak, Bulgar etnoslarının çıkması, 13-14. yy.da Selçuk, Memluk-Kıpçak, Kuman, Bulgar edebî dillerinin, 16-17. yy.da Ermeni yazısıyla Kıpçak evrak dilinin şekillenmesi ve işlemesine neden olmuştur.

6. Tipik fonetik-gramer özellikler.

\section{Ses Bilgisi}

Eski Türk dilleri ile yazılmış metinler çeşitli grafik sistemler üzerinde meydana getirilmiştir. $\mathrm{Bu}$ yüzden ünlü ve ünsüz fonemlerin sadece muhtemel rekonstruksiyonu yap1labilir.

Ünlüler

\begin{tabular}{|c|c|c|c|c|}
\hline \multirow{2}{*}{} & \multicolumn{3}{|c|}{ sira } & \multicolumn{2}{c|}{ arka } \\
\cline { 2 - 5 } & \multicolumn{2}{|c|}{ Ön } & düz & yuvarlak \\
\cline { 2 - 5 } & düz & yuvarlak & $1, \overline{1}$ & $\mathrm{u}, \overline{\mathrm{u}}$ \\
dar & $\mathrm{i}, \hat{\mathrm{i}}$ & $\ddot{\mathrm{u}}, \overline{\mathrm{u}}$ & $\mathrm{a}, \overline{\mathrm{a}}$ & $\mathrm{o}, \overline{\mathrm{o}}$ \\
geniş & $\mathrm{e}, \mathrm{e}, \overline{\mathrm{e}}$ & $\ddot{\mathrm{o}}, \overline{\mathrm{o}}$ & &
\end{tabular}


Eski Türk dillerinde mevcut asli uzun ünlüler yazıda grafik işaretlerle belirtilir: Runik yazıtlarda ā normal a'dan farklı olarak yazılır; Arap harfleriyle yazılmış metinlerde (Kaşgarlı Mahmut) yan yana iki tane elif à’yı gösterir; Uygurca eselerde yan yana bulunan iki ünlü uzun ünlüleri gösterir; Brahmi yazısında uzun, kısa ve yarı ünlü olmak üzere 3 uzunluk derecesi vardır, dolayısıyla 3 farklı işaret söz konusudur.

\section{Ünsüzler}

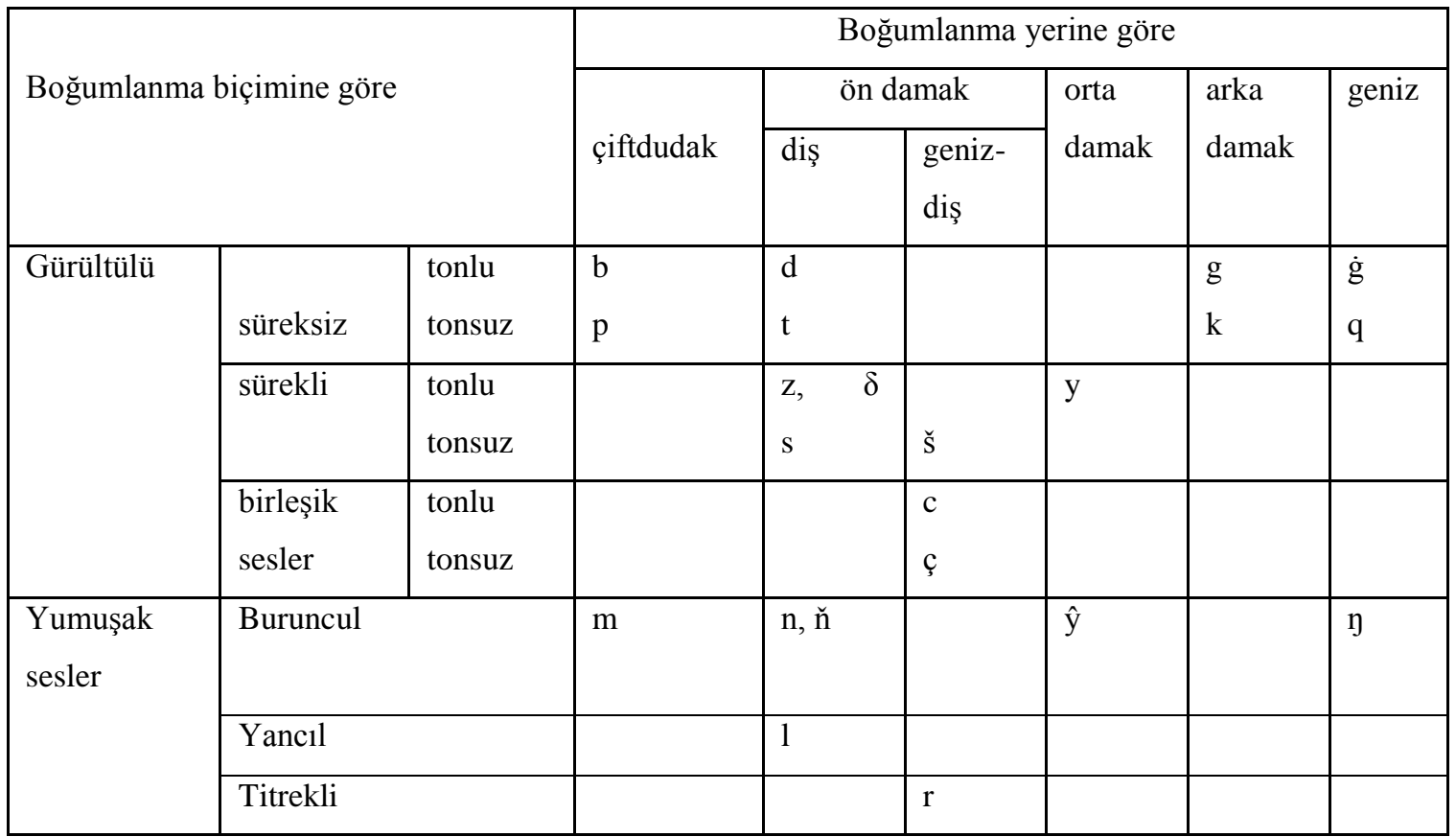

Eski Türk dillerinin çoğunda (runik yazı dili, eski Uygur, Karahanlı-Uygur, Harezm,

Çağatay, Türkî, Selçuk, Kıpçak ve Kuman Türkçesi) kelime başı y’ye rastlanır; kelime başı c Bulgar yazıtları dilinde görülür. Orhun yazıtlarında s-ş mevcuttur. $d-\delta$-y-r hakkında yukarıda bahsedildi.

Fonolojik açıdan ünlü (kalınlık-incelik, düzlük-yuvarlaklık) ve ünsüz uyumlarını belirtmek gerekir. Kalınlık-incelik uyumunun bozulmasına Brahmi metinlerinde rastlanır: alte 'altı', sogeq 'soğuk'. Aynı metinlerde düzlük-yuvarlaklık uyumu kuvvetli bir şekilde korunmuştur: ohol 'oğul', köyöl 'gönül, ruh', türlüg ‘türlü'.

Runik ve eski Uygur metinlerinde ünsüz uyumunun zaman zaman ihmal edildiği görülür. Çok sayıda yan yana tonsuz-tonlu, tonlu-tonsuz, ünlüler arası tonsuzların bulunması Türk lehçelerinde yaygın olan ünsüz uyumunun korunmadığının delilidir.

Bu kural dışı kullanılışlar çoğunlukla Arap grafiğine geçen batı grubu edebî dillerde de görülür. 


\section{Şekil Bilgisi}

Eski Türk dillerinin şekil bilgisine ait en temel özelliği, gramer belirtme usullerinin tek şekilli olmasıdır. Bu, isim ve fiil çekimlerinde açıkça görülür. İsimler tekillik, çokluk, iyelik ve hâl kategorilerine sahiptir.

Çokluk ekleri: -lar /-ler: run. begleri 'begleri', eski Uyg. tıñlıglar 'canlılar', çag. oglanları 'oğulları'.

Nesnelerin toplam sayısı belirtilirken -lar / -ler ekleri kullanılmaz: çağ. on ikki yıl 'on iki yıl'. Özellikle belirtilmesi gereken nesnelerin toplam veya yaklaşık sayısı verilirken -lar / ler kullanılır: tört biñ atlarım-yılqım 'yaklaşık olarak tört bin atım'

\section{İyelik ekleri:}

\section{$\underline{\text { Tekil }}$}

1. ş.e $-\mathrm{m}$

2. ş.e $-\tilde{\mathrm{n}},-\dot{\mathrm{g}},-\mathrm{g}$

3. ș.e $-1 /-\mathrm{i},-\mathrm{s} 1 /-\mathrm{si}$

\section{Çoğul}

$-\mathrm{miz} /-\mathrm{miz}$

-ñı(lar)/- ñiz(ler)

-lari/-leri

Run. eşim qadaşım 'arkadaşlarım, akrabalarım', Eski Uyg. ulusunuzlar 'ülkeleriniz', Bul. erna başı 'haftanın başı'.

\section{Hâl Ekleri:}

Yalın hâl: -ø

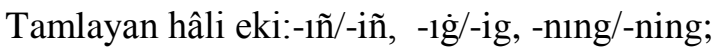

Yönelme hâli eki:-qa/-ke,-a/-e;

Yönelme-yön eki:-qaru/-kerü;

Yön eki:-rr/-ri,-ra/-re, -ru/-rü;

Eşitlik hâli eki:-ca/-ce;

Belirtme hâli eki: -g்1/-ig,-1n/-in,-nı/-ni;

Bulunma hâli eki (bulunma-çıkma hâli eki):-ta/-te,-da/-de;

Çıkma hâli eki: -tan/-ten, -dın/-din,-ran/-ren;

Vasıta hâli eki:-1n/-in.

Karşılaştırın: Run. Türk budunıg atı küsi 'Türk milletinin adı ve ünü’, Çăg. ilnị köbi 'ilin çoğu (büyük kısmı)', Run. abqa 'ava', Eski Uyg. aşqa 'yemeğe', Run. tabġaçgaru ‘ Tabgaçlara' run. ebimrü 'evime doğru', Run. ügüzig '1rmağı', Eski Uyg. biligin 'bilgiyi', Çă̆. ol yerlerni 'o yerleri', ogguzdantan 'Oğuzlardan', Eski Uyg. balıqtın 'şehirden', Çağ. kişidin 'kişiden', Bul. dönyaran 'dünyadan', Run. qaġanımın 'kağanım ile', Eski Uyg. küçin 'güçle'. 
Sıfatlar niteleme (pekiştirme şekli ile) ve belirtme olmak üzere ikiye ayrılırlar. Belirtme sıfatları -lig/-lig,-lıq/-lik,-l1/-li eklerinin yardımıyla yapılır: sekiz adaqlıg 'sekiz ayaklı', biñ yıllıq tümen künlik 'bin y1llık, on bin günlük', çağ. aq1llı va davlatlı 'akıllı ve mutlu', xayratlu 'cesur'.

Runik yazıtlarda 11-29'a kadar birleşik asıl sayı sıfatlarında önce birler basamağındaki arkasından bir sonraki onluğun birimi gösterilir: Eki otuz 'yirmi iki'. 31'den sonraki sayılarda birinci sistemin yanı sira ikinci bir sistem daha kullanılır: onlar basamağındaki sayı, arkasından artuqı kelimesi ve birler basamağındaki sayı: ay artuqı tört kün 'bir ay ve dört gün'. Erken eski Uygur metinlerinde eski sistem (altı yegirmi 'on altı'), son dönem Uygur metinlerinde çağdaş lehçelerinde kullanılan sistem geçiyor (on beş 'on beş').

Sayı sıfatlarının üç türü vardır: Sıra, üleştirme ve kesir sayı sıfatları.

İsim zamirlerinde b-m, e-i değişmesi görülür: ben-men 'ben', sen-sin 'sen', ol 'o', bis(ler) 'biz', siz(ler) 'siz', anlar, alar, olar 'onlar'. İsim zamirlerinin hâl eklerini alması: Run. baña-maña 'bana', biziñe ‘bize', Eski Uyg. bizinte 'bizde', biznidin 'bizden'.

Zamirlerin türleri: İşaret, soru, dönüşlü, belirsizlik, olumsuzluk, topluluk.

Fiiller çatı, şahıs, olumsuzluk, kip, zaman, sıfat fiil, zarf fiil kategorilerine sahiptir.

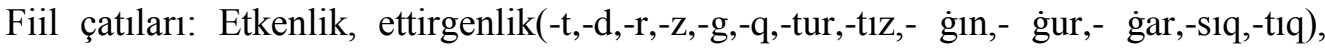
işteşlik (-ş,-s), edilgenlik (-n).

1. tip şahıs ekleri şimdiki ve gelecek zaman çekimlerinde kullanılır:

$\begin{array}{lll}\underline{\text { Tekil }} & & \text { Coğul } \\ \text { 1. ş.e } & \text {-ben,-men } & \text {-biz,-miz } \\ \text { 2. ş.e } & \text {-sen } & - \text { siz } \\ \text { 3. ş.e } & -\varnothing & -\varnothing\end{array}$

2. tip şahıs ekleri geçmiş zaman çekiminde kullanılır:

\section{$\underline{\text { Tekil }}$}

1. ş.e $-\mathrm{m}$

2. ş.e $\tilde{\mathrm{n}},-\dot{\mathrm{g}},-\mathrm{g}$

3. ş.e $-\varnothing$

\section{Çoğul}

$-\mathrm{miz} /-\mathrm{miz}$

-ñı/- ñiz,- ġ1z/-giz

$-\varnothing$

Olumsuzluk fiil köküne -ma/-me olumsuzluk eklerinin eklenmesiyle yapılır.

Fiil kipleri ise şunlardır:

Bildirme, emir, istek, şart, gereklilik. Bildirme kipinin dışında diğer kipler özel yapı

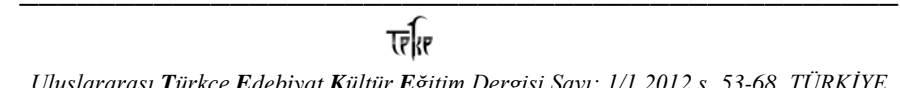


unsurlarına sahiptirler. En çok zaman şekillerine bildirme kipinde rastlanır: Şimdiki-gelecek zaman (1. -r, -yur + 1. tip şahıs ekleri; 2. -a/-e + 1. tip şahıs ekleri), belirli geçmiş zaman (-tı/-dı + 2. tip şahıs ekleri), belirsiz geçmiş zaman (1. -mış/-miş +1 . tip şahıs ekleri; 2 . - gan +1 . tip şahıs ekleri; 3. -b + 1. tip şahıs ekleri; 4. -yuq + 1. tip şahıs ekleri), kesin gelecek zaman (-ar, taçı, -çı + 1. tip şahıs ekleri), muhtemel gelecek zaman ( $-\dot{\mathrm{g} a}(\mathrm{y})+1$. tip şahıs ekleri).

Sıfat fiil ekleri: geçmiş zaman -mış,- gan, -duq, -sıq, şimdiki zaman -r, -yur, gelecek zaman -ar, -taçı, - $\dot{\mathrm{g} m a}$, -g்l1.

Zarf fiil ekleri: -p,-pan,-ban1,-a,-1,-u,-- gal1,- ġaç,-matın,-yın,-sar.

Edatlar 3 türlüdür:

1) İsmin yalın ve belirtme hâlleriyle kullanılan edatlar (birle, sayu, tapa, uçun, üze).

2) İsmin yönelme hâli ekiyle kullanılan edatlar (tegi, teg).

3) İsmin ayrılma hâli ekiyle kullanılan edatlar ( ötrü, kesre, öngi, yan, özge, başqa, beri, ilgeri, nar1).

Kelime yapım yolları ise şöyledir:

İsim türetmenin sentaktik türü (isimden isim yapım eklerinin yardımı ile): -ç1/-çi (meslek eki), -çak/-çek (sıfat eki),-çang/-çık (küçültme eki),-taş/-daş (ortak bir şahsı belirten ek), -lıq/-lik (bolluk), -y/-q (süreci belirtir), -ġı/-gi (işlemin neticesini bildirir).

Kelime türetmenin analitik türü (kelime birleşmeleri): Run. taluy ögüz 'okyanusdeniz', q1z-quduz 'kız-kadın'.

Fiil türetmenin sentaktik yolu (yapım ekleri):-la/-le,-a/-e,-ad/-ed,-1q/-ik,-ra/-re.

Fiil türetmenin analitik yolu: baz q11- 'sakinleştir-', uruş q11- 'savaş-', bitig biti- 'yazı yaz-’.

\section{Cümle Bilgisi}

Eski Türk dillerinin cümle yapısı Türk dilinin genel kuralına bağlıdır: Tamlayan tamlanandan önce gelir. Bu kural tamlamalardaki kelime sıralanmasında açıcça görülür. Tamlayan sıfat, sayı sıfatı, işaret zamiri, zarf, sıfat fiili ile verilebilir: Run. tört buluñ 'dört taraf', az bodun 'küçük halk', Eski Uyg. ulug aş içkü 'büyük ziyafet', Kar-Uyg. telim beg 'çoğunluk beyler', Çăg. kök keşene 'mavi barınak'.

İsim tamlamaları 3 türlüdür:

1) Eksiz, tamlayan ve tamlanan birbirine anlam olarak bağlıdırlar.

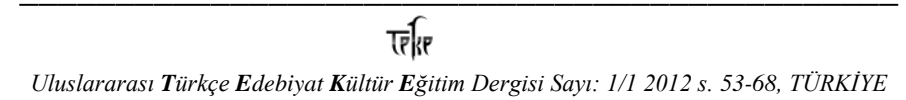


2) Tamlayan yalın hâlde, tamlanan iyelik 3. şahıs ekini alır: Run. ürk og̉uz begleri 'Türk (ve) Oğuz beyleri', Eski Uyg. biş ajun tıñlıglar og̉lanı ' beş dünya canlıları çocukları'.

3) Tamlayıcı tamlayan hâli eki, tamlanan iyelik 3. şahıs ekini alır: Run. Bilge kaġanıñ bodunı 'bilge kağanın halkı', Eski Uyg. bu savnıng basa sonı 'bu sözün (konuşmanın) tam sonu', Çă̆. ilniñ qarılarınıng yakşıları 'ülkenin ihtiyarların en iyileri'.

Eski Türk dillerinde cümle yapı bakımından basit ve birleşik olmak üzere ikiye ayrılır. Yaygın basit cümlede ögelerin sırası sabittir: Zarf-özne-nesne-yüklem:

Run. Eçümüz apamız Bumın kaġan tört buluñug qısmış 'babamız Bumın kağan dünyanın dört tarafını zaptemiş’, Eski Uyg. Öngre ertmiş ötde bu çambudivip ulusta Magaradi atlıg ilik qan bar erti 'Eski zamanlarda bu ülkede Magaradi adında bir hükümdar var idi'.

Anlam vurgusunu bir cümle ögesinden diğerine aktarırken cümle devrik hâl alır: Run. Bengü il tuta olurtaçısan türk bodun 'ebediyen il sahibi olarak yaşayacaksın, Türk bodunu!', Eski Uyg. üç öküklerim birgerü tapıg̨çıları birle qamaġun yumq1 bardılar arıqqa ilinçü meni q1lg̀alı 'üç çocuğum köleler ile birlikte dereye eğlenmeye gittiler'.

Birleşik cümle yapısına göre bağımsız ve bağımlı olmak üzere ikiye ayrılır.

Bağımsız sıralı cümle bağlama durağı veya bağlama edatları ile birleşen iki veya birkaç basit cümleden oluşur. Bağlaçsız sıralı cümle: Run. Tegdimiz yayıdımız 'düşmanı bastık, dağıttık', İlgerü Şantun yazıqa tegi süledim Taluqa kiçig tegmedim 'doğuya Şantun ovasına kadar asker sevkettim, denize az değmedim', Eski Uyg. birisi urug üze bocunumız batı, birisi tolġaqta tınımın altı 'birisi ipi boynuma sardı, diğeri çekiç ile solugumu kesti', Kar-Har. Qar buz qamug erüşdi, tağlar suwı aqışdi 'Kar, buz hepsi eridi, dağlar su akıttı (dağlardan su aktı). Bağlaçlı sıralı cümle türüne (taq1, arap. va, amma, fars. kah...kah) örnekler: çağ. olca yurtıñız da kiter va bayrı yurtıñız da kiter 'ele geçirdiğiniz ülkeler de kendi yurdunuz da gider elden'.

Bağımlı birleşik cümle ana cümle ve ona bağlama durağı, bağlama edatları, yüklemin şekli (-duq, -mış,- gan, -ar, -taçı, -sar/-sa) ile birleşen yan cümleden oluşur. Bağlama edatı ile kurulan birleşik cümle ana cümledeki yüklemin anlamına bağlı: Run. Ol sabıg eşidip qag̉anım ben ebgerü tüşeyin tidi ‘Bu sözleri işitip kağanım 'Ben eve gideyim' dedi’; Kar-Uyg. Baġırsaq boluñ, bolduñ edgü kişi 'Merhametli olun, (öyle) olduğunuzda iyi insan olursunuz'; Çağ. Anı bar bilgil ‘Onun var olduğunu bil'.

Şartlı birleşik cümle (şart kipinin ekleri (-sar/-sa), sıfat fiil ekleri (-ar,-taçı,-duq,-mış) ve özne ile birlikte 'var', 'yok' predıkatıflerinin yardımıyla kurulur): Run. Qaġanım (ben özim 
bilge Tonyukuk ötüntük) ötünçümin eşidü berti 'kağanım (Ben hükümdar Tonyukuk bizzat bulunduğum) ricamı işitti’; Ibar baş aşdımız 'Üzeri çimenlik olan tepeyi aştık'; Eski Uyg. Men ol begniñ öziñe tegdükte, qoyunıntın bir kegde bitig indürüp, maña okudı 'Ben o beyin yanına yaklaştığımda kucağından bir yazı çıkartıp bana okudu'; Tınġalı olurmışta, eng uluġı tigin iki inileriñe ınça tip tidi 'Dinlenirken en büyük şehzade iki küçük kardeşine şöyle dedi'; Kar-Har. Tatıg่-könül arzu q1lsa, begürtse qını 'gönlün istediği gerçekleşse hoştur'. Bağlaçlı birleşik cümle teyin/tiyin, tip, anı üçün, kim (runik yazıtlarda rastlanmaz), ki çünkü bağlama edatlarının yardımıyla kurulur: Run. taşra yorıyur tiyin kü eşidip 'Yurdunun sınırları dışında yaşadığını öğrenip'; Anı añıtayın tip süledim 'onu cezalandırmak için sefere çıktım (asker sevkettim)'; Eski Uyg. Muntada adın taq1 öngi aş içki yoq kim bu alañurmış aç barsıg tigrügülük 'bunun dışında yemek yok ki bu aç parsı diriltmek için'; Çăg. Ulug tag ve kiçig tag ki misniñ kanı bolur 'Uludağ ve Küçükdağ(dır) ki, bakırın çıkarıldığı yer'.

\section{Söz Varlığı:}

Eski Türk dillerinin kelime hazinesinin bir kısmını başka dillerden geçmiş sözcükler oluşturur. Runik harfli yazıtların ve eski Uygur metinlerinin bünyesinde Sanskritçe, Soğdca, Çince, Tibetçe kelimeler mevcut. Bunlar unvanlar, etnik ve coğrafi yer adlarıdır: maqraçmaxaraç (Sansk. maharaja) 'büyük hükümdar': Maqaraç tamġaçı-özel isim ve unvan; soġdaq (Soğd. sıwduk) etn. 'soğdaklar', şad (Soğd.) Türk ve Uygur Kağanlıklarında en büyük askerîidari unvanlardan biri, şadapıt begler 'yüksek rütbeler'; qunçuy (çin. kong-çu) 'prenses, asil aileye mensup kadın' sangün-senun (Çin. tsiong-kın) 'yüksek rütbe, unvan’; tabgaç (çin. thagbar, thag-bat: Kuzey Çin'de Kuzey Wei hanedanını (M.Ö. 386-534) kuran boy) 'Çin, Çinli’; Şantung (Çin. Şandun, Şang-tong) Şantung yazı: coğ. 'Şantun ovası'; Tüpüt (Tib. Te-Bod 'Yukarı Tibet') 'Tibet, Tibetli'.

Eki Uygurcada yabancı dillerden geçmiş kelime (bunlara Toharca, Farsça ve Arapçayı eklemek lazım) sayıca daha çok ve söz varlığı yelpazesinin çeşitli alanlarında (din, felsefe, tıp, astonomi, şiir, ticaret, günlük hayat, insan, halk adları) yaygın olarak kullanılıyorlar: açari-açarı (Sansk. acarya) 'hoca, danışman', adiştit (Sansk. adhisthita) 'rahmet, nimet', vixar (Sansk. vihara) 'manastır, ibadethane', vaçir (Sansk. vajra) 'elmas', 'asa', nirvan (Sansk. nirvana) 'nirvana, tamamen rahatlık durumu', vidya (Sansk. vidya) 'bilgi, bilgelik', aditya (Sansk. aditya) 'güneş', 'güneş günü, haftanın yedinci günü'; rşi (Sansk. rsi) 'eski kutsal marşları söyleyen kimse, şair', uşır (Sansk. usıra) bitki adı, pitpidi (Sansk. pippali) bot. 'uzun biber', Kumari (Sansk. kumara) özel isim, Kupiri (Sansk. kumbkıra) özel isim, bir ilahinin ismi; liçevi (sanskr. licchavi) halk adı, buşı (çin. buşi, po-ş1) 'sadaka', baqş1 (Çin. boşi, bag-şi) 'hoca, danışman', vu (Çin. bvı) 'tılsım', lu (Çin. lun) ‘ejderha, yılan', labay (Çin. lua-pai) 'istiridye

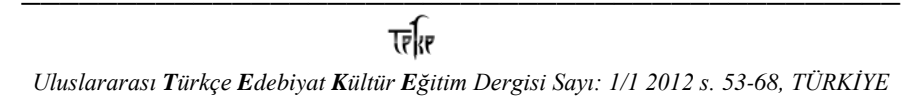


kabuğu, bornoz', lenxua-linxua (Çin. lien-xwa) 'lotos çiçeği', arırı (Tib. arura) bitki adı, lıgso (Tib. legs-so) 'iyi, hoş', sabarir (Toh. spharir- sanskr. sphatika) 'billur', banit (Toh. panitsanskr. phanita) 'şerbet', nom (Soğd. nwn) 'dinî öğretim, kitap, yazma', vrxr ( $S o g ̆ d$.) 'manastır'.

Eski Uygurcaya az sayıda Arapça ve Farsça kelimeler geçmiştir: niv (Far. nev) 'bahadır, kahraman', nişan (Far.) 'mühür, damga', kegde-kegede (Ar.) 'kağıt', qacat (arap.) 'çok yüksek', qaq-hak (Ar.) 'hak, değer, görev'. Runik ve eski Uygur yazıtlarından batıda bulunan Karahanlı-Uygur, Harezm, Çağatay, Türk, Selçuk, Memluk-Kıpçak ve Bulgar metinlerinin esasını Arapça ve Farsça kelimeler oluşturur. Arap.: din, ayet, vaaz, dua, levh, mürüvvet, rahat, rahmat, rıza, sa' det, dünya, vefa, liv aş 'kurbanlık yemek', vudd 'sevgi'; fars.: ruza 'oruç', durud 'dua', raz 'sır', ruzgar, revan 'ruh, hayat'. Terim olarak Sanskritçeden, Çinceden geçen kelimeler: çından-çıntan (Sansk. candana) 'güzel kokulu sandana ağacı', çurnı (Sansk. curna) 'şifalı toz', sart (Sansk. sartha) 'tüccar', burxan-burqan-furxan (Çin. bvır) 'budda, burhan, put, elçi', lav (Çin. lab) 'damga için mum'. Doğuda Şamanizm, Buddizm, Maniheizm kültürlerinin etkisi altında meydana getirilen yazıtların söz varlığı Sanskrit, Soğd, Tohar, Çin dillerinden alıntıları içerir; Müslüman kültürünün kanadı altında gelişen batı grubu edebî mahsullerin kelime hazinesini ağırlıklı olarak Arapça ve Farsça kelimeler teşkil eder.

\section{Kaynaklar}

BASKAKOV, A. N. (1969). Vvedeniye V İuзeniye Tyurkskih Yazıkov (Türk Dillerini Incelemeye Giriş), Moskova.

NADElyAEV, V. M. vd. (1969). Drevnetyurkskiy Slovar (Eski Türkçe Sözlük). Leningrad.

KONONOV, A. N. (1972). İstoriya İzuçeniya Tyurkskih Yazıkov V Rossii (Rusya'da Türk Dillerini Inceleme Tarihi). Leningrad.

KONONOV, A. N. (1968). Tyurkskaya Filologiya v SSSR ( Sovyetler Birliği’nde Türk Filolojisi), 1917-1967. Moskova.

MALOV, S. Y. (1951). Pamyatniki Drevnetyurkskoy Pismennosti (Eski Türk Yazılı Abideleri), Moskova. Leningrad.

MENGES, K. H. (1968). The Turkic Languages And Peoples. Wiesbaden.

Philologiae Turcicae Fundamenta. (1959). Wiesbaden.

TENIŞEV, E. R. (1991). Yazık i Kultura // Nauka İ Çeloveçestvo ('Dil ve Kültür' İlim ve Insanlık). Moskova.

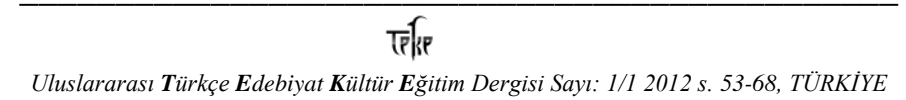

International Journal of Turkish Literature Culture Education Volume 1/1 2012 p. 53-68, TURKEY 
Tyurkskoe Yazıkoznanie Za Şestdesyat Let // Sovetskaya Tyurkologiya ('60 Sene İçinde Türk Dilbilimi' Sovyet Türkolojisi). (1977). No: 6.

Tyurkskiye yazıki // Yazıki narodov SSSR ('Türk Dilleri’ Sovyetler Birliği Halklarının Dilleri). (1966). C. 2, Moskova. 